\title{
Projections of Brazilian biomes resilience and socio-environmental risks to climate change
}

\author{
Projeções de resiliência dos biomas brasileiros e riscos \\ socioambientais às mudanças climáticas
}

Patrícia F. Pinho ${ }^{a}$

Luciano J. S. Anjos ${ }^{b}$

Saulo Rodrigues-Filho ${ }^{c}$

Diogo V. Santos ${ }^{d}$

Peter M. Toledo

a Institute of Advanced Studies (IEA) - University of São Paulo (USP), São Paulo, SP, Brazil E-mail:pinhopati@gmail.com

${ }^{b}$ Federal Rural University of the Amazon, Parauapebas, PA, Brasil E-mail: Ijsanjos@gmail.com

' Sustainable Development Center, University of Brasilia (CDS/UnB), Brasilia, DF, Brazil E-mail: saulofilhocds@gmail.com

${ }^{d}$ Ministry of Science, Technology and Innovations (MCTI), Brasília, DF, Brasil E-mail:diogo.santos@mctic.gov.br

${ }^{e}$ Earth System Science Center (CCST), INPE, São José dos Campos, SP, Brazil E-mail: peter.toledo@hotmail.com

Data and results presented in this article were developed under the project of the "Fourth National Communication and Biennial Update Reports of Brazil to the Climate Convention", coordinated by the Ministry of Science, Technology and Innovations, with the support of the United Nations Development Programme and resources of the Global Environment Facility, to which we offer our thanks.

\section{ABSTRACT}

Climate change has been considered, at a global level, as one of the main anthropogenic drivers of environmental transformation, especially on biomes, ecosystems and the most vulnerable population. In this regard, the concept of resilience has been widely used in ecology to explain the ecosystem transition thresholds by which forests and other habitats are able to restructure in the face of various external disturbances. However, the concept of resilience in facing climate change impacts and risks through the lens of socio-environmental risks in Brazil is still underdeveloped, especially at the biome 
level. This article uses the theory of critical transitions to ecological niche distribution modeling in future global warming scenarios by the end of the century, in order to highlight the change in ecological resilience of the Amazon, Caatinga, Cerrado, Atlantic Forest and Pampa biomes, and how the changes in resilience can lead to an increased exposure, vulnerabilities and risks to socio-environmental security. This article shows how an interdisciplinary approach bringing together modeling of biome resilience may be a tool to support decision making and public policies on mitigation and adaptation to climate change and reduce risks to socio-environmental security.

Keywords: Biomes. Modeling. Resilience Ecosystem services. Climate Change Socio-environmental security.

\section{RESUMO}

As mudanças climáticas são consideradas globalmente um dos principais vetores de transformações socioambientais, sobretudo em biomas, ecossistemas e populações mais vulneráveis. Nesse contexto, $o$ conceito de resiliência tem sido frequentemente empregado, sendo utilizado na ecologia para entender os limiares de transição ecossistêmicos pelo qual florestas e outros habitats conseguem se estruturar diante das diversas perturbações externas. No entanto, o conceito de resiliência ante os impactos e riscos das mudanças climáticas pelas lentes de riscos socioambientais no Brasil ainda é pouco desenvolvido, sobretudo na escala de biomas. Neste artigo, utilizamos a teoria das transições críticas à modelagem de distribuição de nicho ecológico em cenários futuros de aquecimento global até o final do século, a fim de evidenciar a alteração da resiliência ecológica dos biomas da Amazônia, Caatinga, Cerrado, Mata Atlântica e Pampa, e de que forma as alterações na resiliência podem levar a um aumento da exposição, vulnerabilidades e riscos à segurança socioambiental. $O$ artigo mostra como a abordagem interdisciplinar na modelagem de resiliência dos biomas pode ser um instrumento auxiliar para tomada de decisões no âmbito das políticas públicas de mitigação e adaptação às mudanças climáticas $e$ redução de riscos à segurança socioambiental.

Palavras-chave: Biomas. Modelagem. Resiliência. Serviços Ecossistêmicos. Mudanças Climáticas. Segurança Socioambiental.

\section{INTRODUCTION}

In Brazil, climate modeling analyses (using baseline scenario from 1970 to 2050) of the cumulative effects of climate and non-climate drivers in the loss of species show that land-use change (LUC) forcing has a critical historical role in changes in the Amazon, Cerrado, Caatinga and Atlantic Forest biomes, as well as marine ecosystems (Carlos A. Joly, Maíra C. G. Padgurschi e et al., 2018). However, since 1970, climate change started to have an increased role in biodiversity loss, posing significant risks to the delivery of ecosystem services in 2050 (Ometto et al., 2018).

Climate change projections for Brazil point at significant impacts of extreme rainfall regime changes in the form of floods and landslides, a strong increase in heat extremes and heat waves (mainly in urban areas), and droughts (AMBRIZZI et al., 2007; MARENGO e SCARANO, 2016). It is critical the fact that these climate impacts on top of processes arising from land-use changes within the ecosystems happen in a non-linear way, and are heterogeneous in time and space and are still poorly elucidated, as is the debate of ecological tipping points (LENTON, 2013; LENTON et al., 2008).

Thus, it is important to recognize the temperature, rainfall and humidity thresholds by which ecosystems (oceans and forests) will incur in tipping points, so that emerging systemic socioenvironmental risks may be foreseen and managed (OPPENHEIMER et al., 2014). Recent scientific evidence suggest that current climate conditions and future change projections impose significant environmental, economic and social burdens to tropical countries in the Global South like Brazil, which will experience severe economic impacts and risks in a non-linear and heterogeneous way 
(BURKE, HSIANG e MIGUEL, 2015). However, in theory, the economic losses and socio-environmental costs might would be minimized if adaptation strategies is implemented (CARLETON e HSIANG, 2016).

In this context, this article aims at contributing with the socio-environmental resilience analysis in an integrated way the biomes level (Amazon, Cerrado, Caatinga, Atlantic Forest and Pampa), taking into consideration their greatest vulnerabilities to climate change. This study aims at contributing to reduce risks in different sectors of the economy, human well-being and population health, especially among the most vulnerable ones. For this purpose, the results presented might provide a technical support to embase decisions on socioeconomic development and urban planning policies, and setting up priority areas for conservation within the agenda of mitigation (e.g. reforestation) and adaptation to climate change.

\section{INTEGRATED METHODOLOGICAL FRAMEWORK}

Three distinct phases have been developed in order to compose the analysis of terrestrial biomes changes in the face of climate change and their consequences for what has been defined herein as socio-environmental security ${ }^{1}$. First, current and future biome resilience (Amazon, Caatinga, Cerrado, Atlantic Forest and Pampas) were assessed by climate niche distribution modeling. Then, the results were assessed from the perspective of specific Land-use change (LUC) forcing for each of the biomes, except the Pantanal ${ }^{2}$. After data triangulation, a broader discussion is presented on the possible socioenvironmental risks to climate change in the country's main biomes.

The ecological resilience analyses per biome were carried out by climate niche distribution, taking into consideration the temperature and rainfall variations for the current period (1960-1990) and future climate change scenarios representing different global average temperature warming $\left(1.5^{\circ} \mathrm{C}, 2^{\circ} \mathrm{C}\right.$ and $4^{\circ} \mathrm{C}$, respectively) for the Representative Carbon Pathway (RCP 8.5). Qualitative and quantitative LUC analyses were considered for the present and future projections (when available) in the biomes via rates of deforestation, dependency and fragility of indigenous peoples and traditional communities and family farming, the expansion of agriculture and commodities, urbanization and consumption, which have a central role in changing ecosystems and habitats, and synergistically interact with climate changes. The next section approaches the conceptual premise and state-of-the-art of ecological resilience and distribution modeling.

\section{CONCEPTUAL PREMISE AND STATE-OF-THE-ART OF ECOLOGICAL RESILIENCE AND DISTRIBUTION MODELING}

The classic definition of resilience, by Holling (1973), still widely used, and states that ecological resilience is the measure of disturbances that a system can tolerate before undergoing a change to a different stable state. This concept suggests that there are eco-physiological thresholds that guarantee the adequate functioning of natural ecosystems (referred to as biomes herein) along an environmental gradient (e.g. temperature, rainfall). In theory, the gradual changes under the environmental conditions may lead to an ecosystem to lose its resilience, and thus reducing its self-organization capacity following a disturbance, and as a result compromising its structure and functioning (SCHEFFER et al., 2009). The theory of ecological stability and critical transitions provides that if a certain environmental threshold (e.g. temperature and precipitation) is exceeded, it may trigger a critical transition event, which would lead this low-resilience system to an alternative stable state (FOLKE et al., 2004; Gunderson, 2000; Scheffer et al., 2001). In other words, an ecosystem would transform into another type of ecosystem, undergoing an environmental reconfiguration under a specific geographic space. In the current context of accelerated climate change, it may be expected that such ecological changes act like an important driver to threatened ecosystems by altering its resilience (ANADÓN, SALA e MAESTRE, 2014).

1 | Socio-environmental security is defined herein as the way in which human life and the respective livelihoods are ensured within the environment, whether in the provision of water, energy, food, material goods and cultural attributes (as adopted by the Fourth National Communication of Brazil to the UNFCCC, 2019).

2 | Modeling analyses have not been undertaken for the Pantanal, therefore, it is not included in this article. 
From this narrative perspective, in order to address ecosystem changes and their consequences for biomes' socio-environmental security in Brazil, this paper first sought to assess current and future resilience of ecosystems in the Amazon, Caatinga, Cerrado, Atlantic Forest and Pampas biomes by using the distribution of climate niche concept and modeling, and, in parallel, analyze the impact chain associated with land-use change (LUC) forcing.

Ecosystem resilience analyses per biome will be presented for current and future climate change scenarios, representing different warming levels $\left(1,5^{\circ} \mathrm{C}, 2^{\circ} \mathrm{C}\right.$ and $4^{\circ} \mathrm{C}$ for RCP 8.5), and reflecting time scales focused on 2025, 2045 and 2085, based on data observed at present and in the past. Given that land-use changes (LUC) have a central role in ecosystems and habitats alterations, which are exposed to climate change impacts, providing a synergistic process of positive feedback from environmental degradation and socio-environmental risks, a qualitative and quantitative assessment of such current and future changes in biomes was made. As a result, the integration of present and future climate niche analysis with the assessments of current and trendy LUC will infer on potential socio-environmental resilience in the context of climate change for the country.

\subsection{MODELING TERRESTRIAL BIOMES RESILIENCE IN BRAZIL}

With the purpose of estimating Brazil's terrestrial biomes resilience, the assumption is that each type of vegetation is adapted to a certain range of current temperature and rainfall conditions. If, in the future, a biome is exposed to different climate conditions, to which it is not adapted to, its resilience might be reduced to an extent in which it would lead to another stability level, and resulting in a dominant vegetation pattern that is different from the current one. Thus, computer models were projected to verify what would be the likelihood of biomes' vegetation types changes, if they were submitted to different temperatures and rainfall conditions other than the current ones.

Measuring the ecological resilience in an objective manner is not a trivial task (NIKINMAA et al., 2020), especially at large spatial scales (REYER et al., 2015). With the advent of computational resources with high processing power and the large availability of massive amounts of data, several approaches have been proposed to bridge this gap. For example, Hirota et al., (2011) used a logistic regression to measure rainfall effects on stable forest and savannah states for South America.

Using a different approach, Comer et al., (2019) created an index to assess habitat vulnerability to climate change by modeling resilience from the inclusion of factors such as intact landscapes, invasive species, alteration of the fire regime, forest insects and risk of diseases. In a recent review, Chambers, Allen e Cushman, (2019) tried to operationalize the concept of resilience from a explicitly spatial conceptual framework. The approach used herein differs from the previous ones because it incorporates the concept of ecological resilience in the scope of the critical transitions theory to ecological niche modeling (ANJOS e TOLEDO, 2018).

In this study, in order to assess the potential response from the Brazilian terrestrial biomes in the face of climate change, it is assumed that each biome represents a stable state within a large-scale multi-stability ecosystem system (SCHEFFER et al., 2012). This assumption has a strong empirical support, given that each biome presents an adaptive phenotypic response that is species peculiar to the prevailing climate conditions of a certain region, modulated and consolidated throughout the evolutionary history of the biomes (DONOGHUE e EDWARDS, 2014)andwhy have some biome shifts been more frequent than others? To orient this line of research we develop a conceptual framework in which the likelihood of a biome shift is a function of (a. With the purpose of increasing spatial accuracy in determining and classifying biomes, the ecoregion polygons as defined by (Olson et al., 2001), were used. Moreover, in order to avoid bias caused by sub-sampling (due to geopolitical borders), the entire range of biome climate response was considered for South America. 
Then, the polygons of each biome were converted into a presence-absence binary data, under a point vector format with spatial resolution of $0.20^{\circ}(\sim 24 \mathrm{~km})$. A geo-referenced signature was attributed to each presence or absence, with longitude and latitude, covering all the range occupied by biomes in South America. Such information on presence-absence were then used as inputs in building correlative distribution models based on the ecological niche. Altogether, 21,441 points were included in the analyzes as sample units, covering part of South America (Figure 1A). When a certain biome was modeled, the original presence data was taken into consideration, and all other points in the sample cloud were considered to be absences from that respective biome.

In order to model and predict the relationship of terrestrial biomes with the dominant climate, four critical climate predictors for terrestrial ecosystems were used (Lehmann et al., 2014; Oliveras e Malhi, 2016). These variables were selected from two variability eco-climate axes, as per (Anjos e Toledo, 2018): (1) moisture availability - annual accumulated rainfall (Figure 1C) and precipitation seasonality (Figure 1E) and; (2) energy availability- annual average temperature (Figure 1B) and annual temperature range (Figure 1D). These variables were obtained from the Eta Regional Model, under the HadGEM2-ES global model boundary conditions (Eta-HadGEM2 ES), developed by the National Institute for Space Research (INPE, in the Portuguese acronym) (Chou et al., 2014) with $0.20^{\circ}(24 \mathrm{~km}$ ) spatial resolution, covering all South America. Future climate projections encompass three time periods associated to global average warming for IPCC's RCP 8.5: $1.5^{\circ} \mathrm{C}$ (2011- 2040); $2^{\circ} \mathrm{C}$ (2040-2070); $4^{\circ} \mathrm{C}$ (2070- 2099).

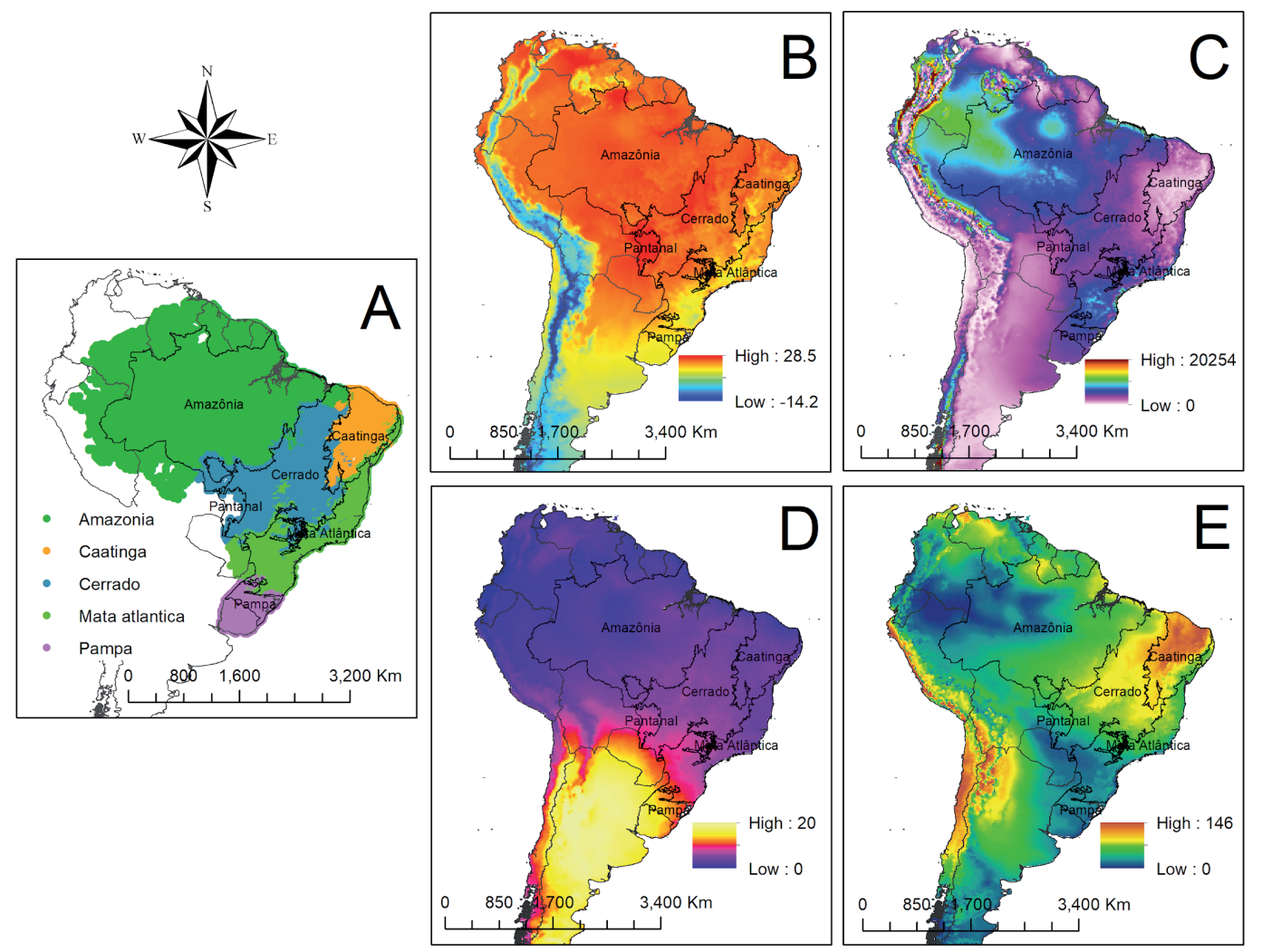

Figure 1 | A presents occurrence for each biome, taking into consideration its original distribution. The set of climate predictors used in the modeling are presented in B- average annual temperature; Cannual accumulated rainfall; D- annual temperature range; E- rainfall seasonality.

Source: Authors.

In order to model the distribution of terrestrial biome stable states, the biomod2 package was used (THUILLER et al., 2009) written in R language (R CORE TEAM, 2020). Distribution models were calibrated by using presence-absence data of each stable state combined to selected climate predictors. The models were run using nine different methods available in the biomod2 platform: Bioclim (SRE), Classification 
Tree Analysis (CTA); Random Forest (RF); Generalized Linear Models (GLM); Generalized Aditive Models (GAM); Generalized Boosted Models (GBM), Function Discriminant Analysis (FDA); Artificial Neural Networks (ANN); Multiple Aditive Regression Splines (MARS). For each method, 10 replicas with 75\% partition for training and $25 \%$ for testing were run. The accuracy assessment of models in each method was carried out with True Skill Statistics (TSS) and Receiver Operating Characteristic (ROC) metrics.

Each method presents distinct biological, mathematical and/or statistical assumptions, and may produce different results from the same input data set. According to (RANGEL e LOYOLA, 2012), taking into consideration the characteristics of each modeling method, they may be grouped as 'aquariums' (Bioclim), 'turbines' (GLM, GAM, MARS, FDA) or 'safes' (CTA, RF, GBM, ANN). In this regard, the creation of a consensual model among the different methods in order to minimize the effects of uncertainties associated with each modeling method was the option adopted. Therefore, the best models of each method to compose the 'ensemble' were selected using the TSS metric, that measures quality combining sensitivity and specificity of the models (ALLOUCHE, TSOAR E KADMON, 2006)

For threshold purposes, those models with TSS values greater than or equal to 0.6 were considered accurate. The consensual distribution model was obtained by the arithmetic mean of the best models of the different methods (Diniz-Filho et al., 2009). A consensual distribution model was built for each biome from the selection of models that presented TSS $>=0.6$.

\section{RESULTS OF BIOME RESILIENCE MODELING}

Figure 2 indicates the result of biome distribution modeling for the current climate, which explicitly shows that there is little overlap in the occupation of climate space (temperature and rainfall) among the biomes in Brazil. The pattern observed is that each biome occupies a specific range of the climate environmental gradient, and along these lines, they all present relatively high resilience, with low or average resilience in their transition ranges.

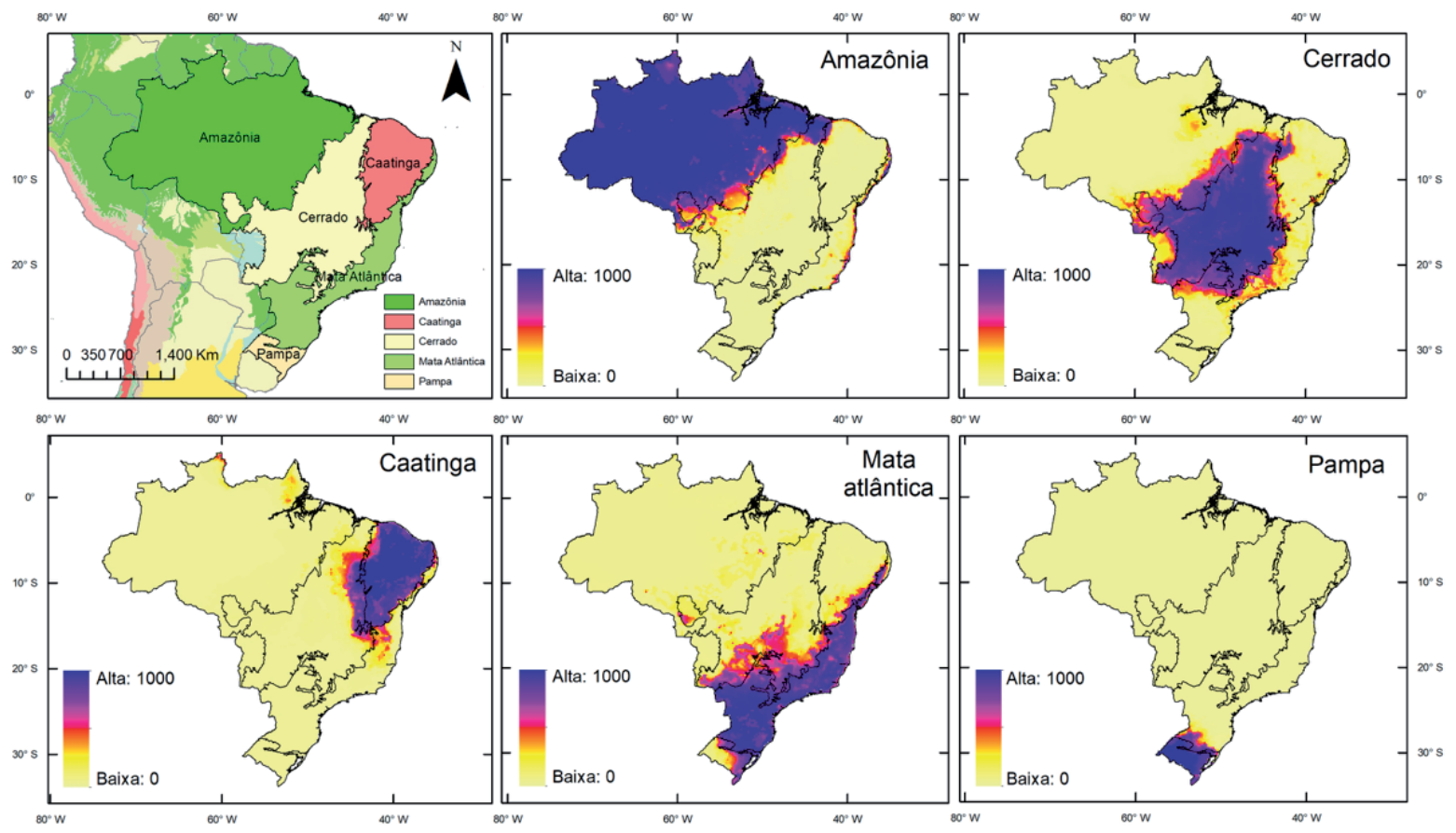

Figure 2 | Current biome resilience (low: 0 to high:1000) for eco-climate dynamic. 
The varying resilience range represents the dominance level of a certain biome within its original biogeographic borders. The high values in this variable indicate that a biome has strong predominance in comparison with other biomes, that is, it presents greater eco-climate resilience. On the other hand, low values of dominance level point at lower resilience and greater susceptibility to transition events into other ecosystem stable states.

In this regard, when the resilience range is assessed at a two-dimensional climate plan under different climate scenarios (columns), it is possible to detect changes at the biome dominance level from shifting climate conditions that are not analogous to the present ones (Figure 3). For instance, this figure shows that the Amazon biome is more vulnerable to critical transition in future scenarios due to an increase in the average temperature ( $y$ axis) and decrease in annual accumulated rainfall ( $x$ axis) under its biogeographic domains. Likewise, in the same biome, small changes in temperature seasonality ( $y$ axis) and rainfall ( $x$ axis) caused strong alterations in the resilience range, thus suggesting greater vulnerability to critical transition events due to projected climate change.

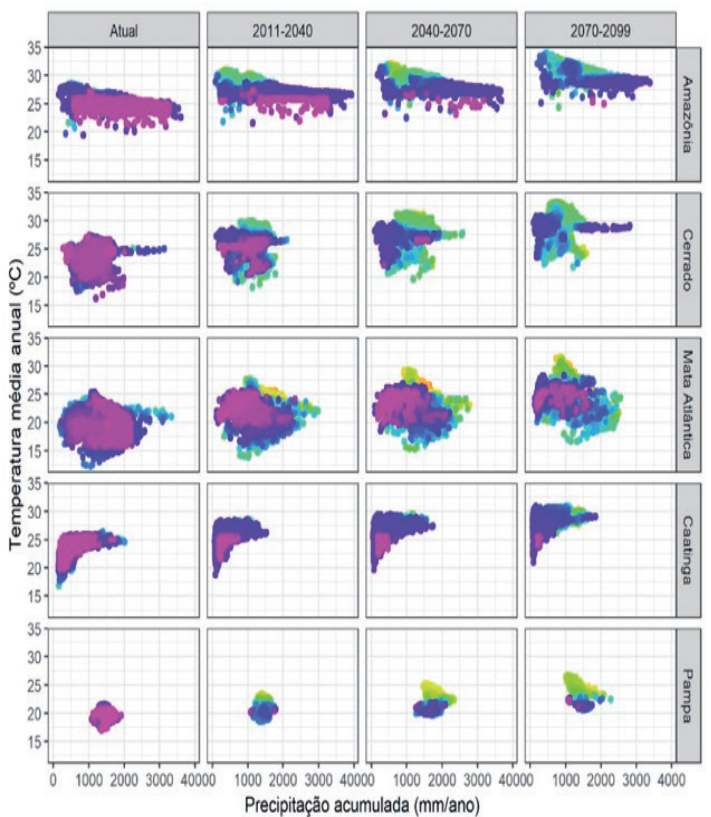

Accumulated Rainfall

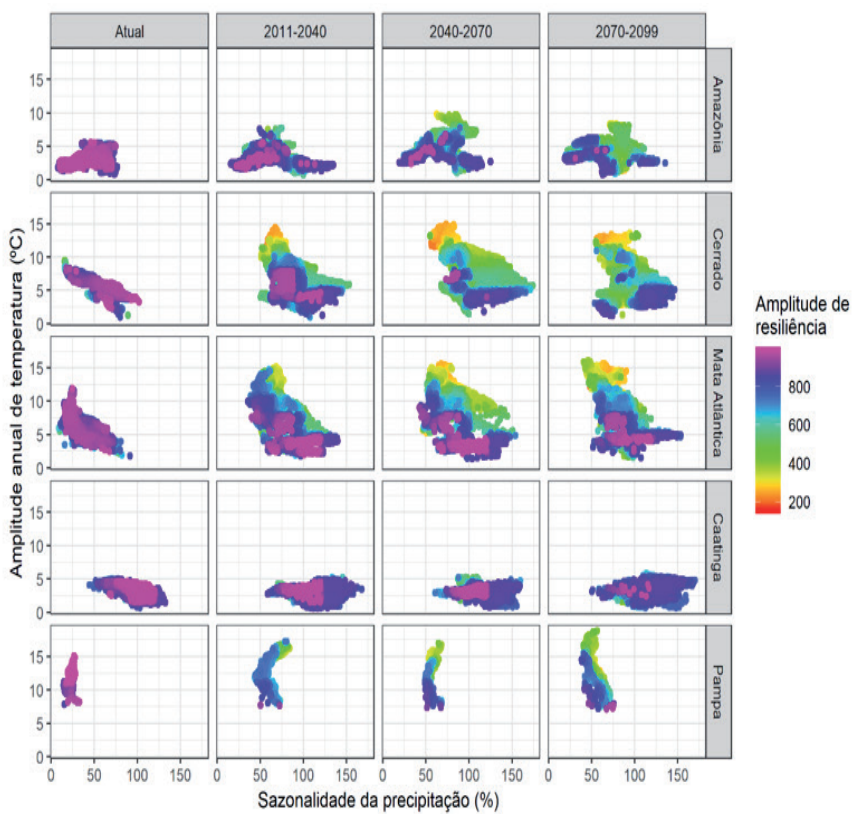

Rainfall Seasonality

Figure 3 | Current and future Biome Resilience Range related to warming levels of $1.5^{\circ} \mathrm{C}, 2^{\circ} \mathrm{C}, 4^{\circ} \mathrm{C}$ at the climateniche modeling two-dimensional space. The set of variables used were average annual temperature $\left({ }^{\circ} \mathrm{C}\right)$ and accumulated rainfall (mm/year), and annual temperature range $\left({ }^{\circ} \mathrm{C}\right)$ and rainfall seasonality $(\%)$.

Source: Authors.

\section{AMAZON}

The resilience range in the 'current' eco-climate space occupied by the Amazon (high levels of rainfall and temperature) shows the forest's high adaptive capacity and is represented in Figure 3. Figure 3 also shows that the forest's change threshold is sensitive to annual rainfall decrease from $1,500 \mathrm{~mm} /$ year. Projections show a significant alteration in resilience range and evidence its loss in most of the Amazon biome, starting at a warming level of $1.5^{\circ} \mathrm{C}$, focusing on high resilience only in the western part of the biome, but with significant retraction in higher warming levels.

Therefore, downward trends in rainfall and humidity would affect the forest's resilience. This scenario has been documented for this biome (ZANIN, MACHADO e ALBERNAZ, 2016), resulting in increased 
tree mortality, reduced forest biomass and increased incidence of fire episodes, culminating in the loss of biodiversity and ecosystem services (ANJOS e TOLEDO, 2018; OMETTO et al., 2014).
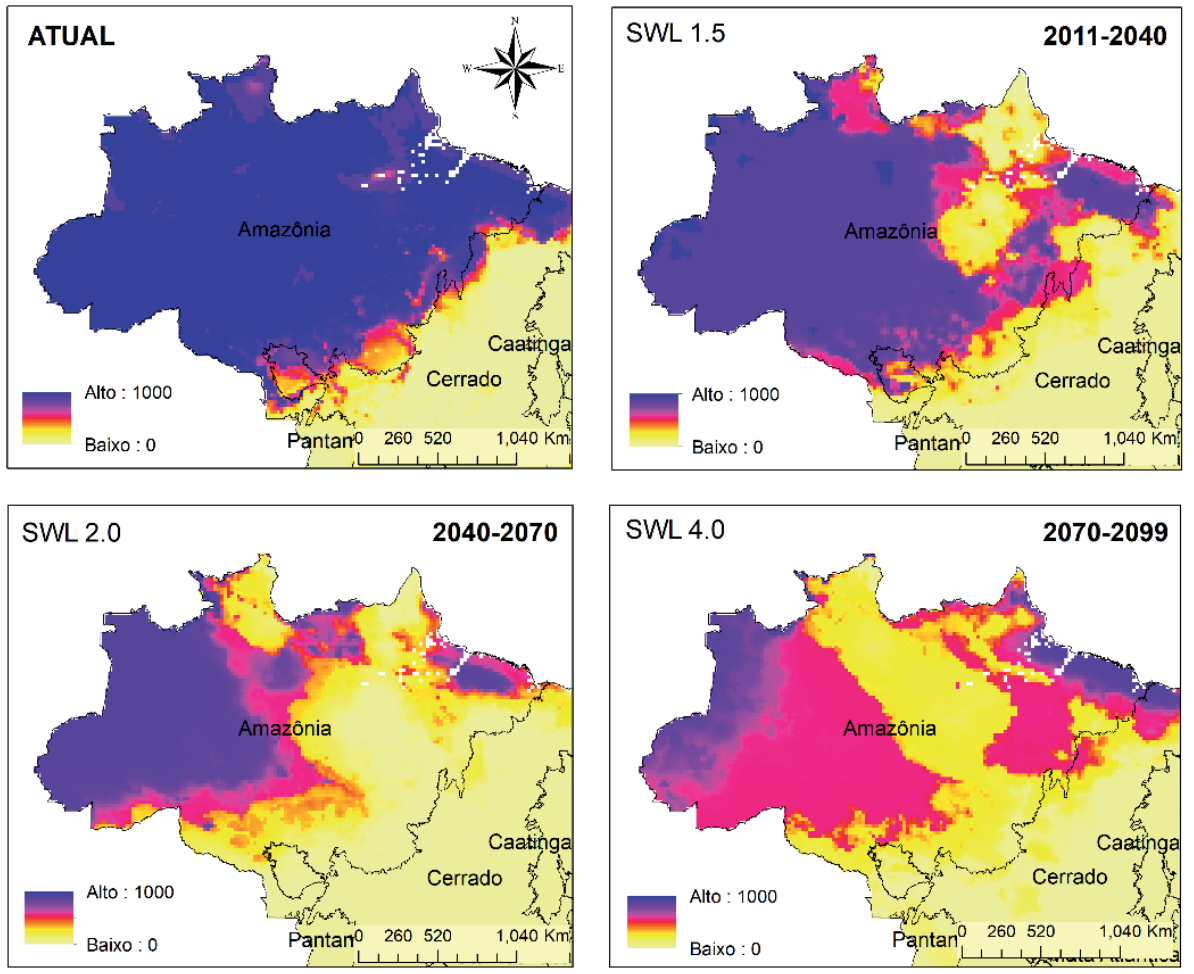

Figure 4 | Projection of Resilience alterations for the Amazon (low: 0 to high:1000) at $1.5^{\circ} \mathrm{C}, 2^{\circ} \mathrm{C}$ and $4^{\circ} \mathrm{C}$

Source: Authors.

\section{CAATINGA}

For the Caatinga, the high resilience range is very narrow for the current period, which means it is a low-resilient biome to eco-climate variables (temperature and rainfall), as shown in Figure 5. Future projections show another stable state, more desert-like, with high temperatures and critical rainfall levels, with no biomass. These factors indicate a greater tendency towards an aridization process, which, together with environmental degradation leads to an expansion of deserted areas, decreasing the Caatinga's resilience range.

Projections indicate that with an increase in warming levels to $1.5^{\circ} \mathrm{C}$, the biome expands to the coastal zone, southern and central-western regions of the country, with high resilience. From a warming level relative to $2^{\circ} \mathrm{C}$, more expansion occurs, overlapping with the Atlantic Forest biome and advancing in the Cerrado. For a warming level at $4^{\circ} \mathrm{C}$, the biome will have high resilience range in areas that used to be occupied by the Atlantic Forest, and will also expand to the center-west region, occupying the Cerrado biome. Results of this modeling for the Caatinga biome have also been described by Zanin, Machado and Albernaz, 2016, and are compatible with the biome's results. 

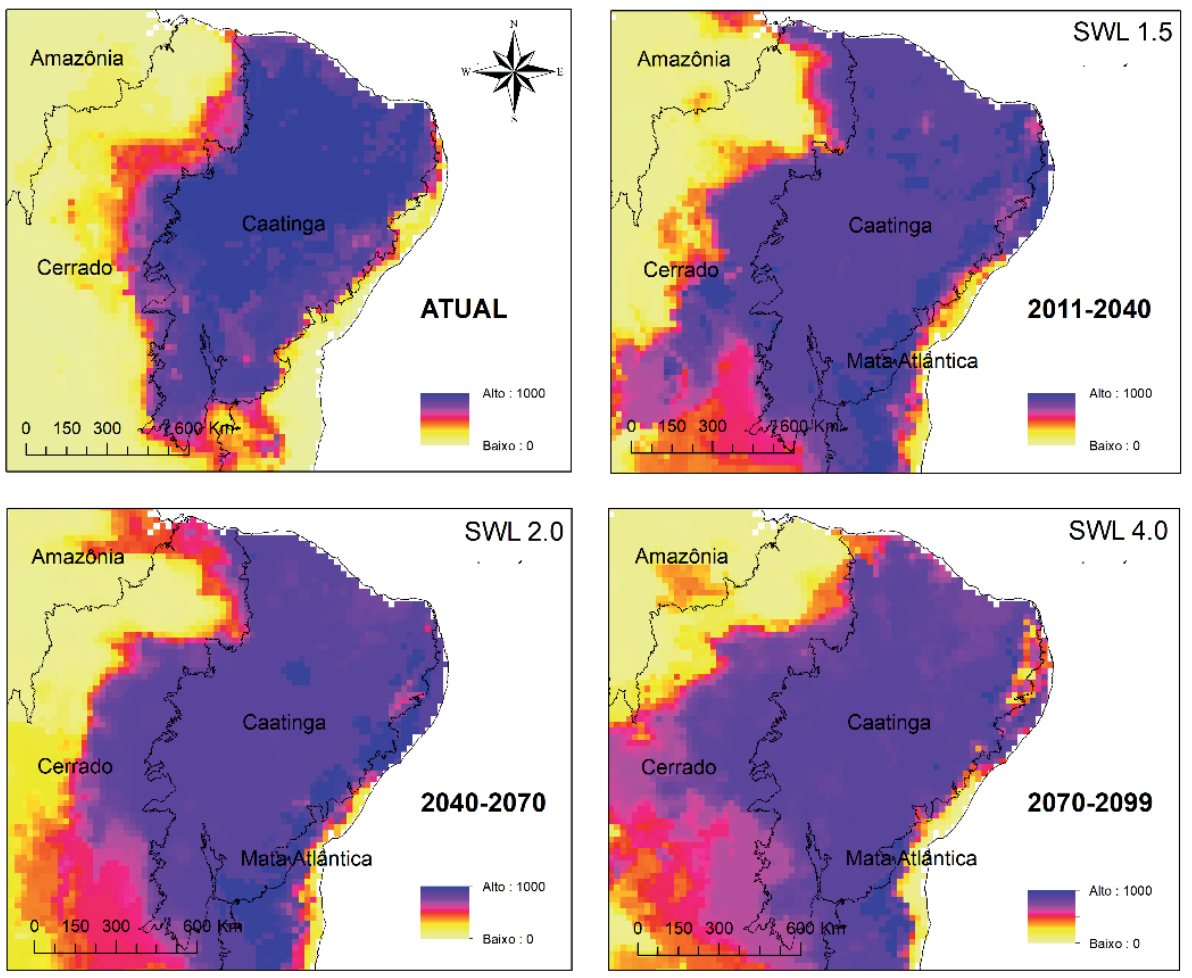

Figure 5 | Projection of Resilience alterations for the Caatinga (low: 0 to high:1000) at $1.5^{\circ} \mathrm{C}, 2^{\circ} \mathrm{C}$ and $4^{\circ} \mathrm{C}$ Source: Authors

\section{CERRADO}

The resilience range is higher in the Cerrado, and greater than that in the Amazon, presenting relatively sensibility in relation to increased rainfall $(\sim 2,500 \mathrm{~mm} /$ year $)$ and higher tolerance to high temperature gradient at present, as per Figure 6 . This biome also presents an intermediate level of biomass, within the transition between increased or reduced resilience. Projections based at the current period show that from a warming level at $1.5^{\circ} \mathrm{C}$, the Cerrado expands to areas previously occupied by the Amazon biome, and also areas occupied by the Atlantic Forest and coastal region. Projections based on a warming level relative to $2^{\circ} \mathrm{C}$ show that the biome significantly shift towards occupying a large part of the Amazon and Atlantic Forest. For a warming level at $4^{\circ} \mathrm{C}$, modeling results show a drop in resilience in the region currently occupied by the Amazon biome. In this scenario, the coastal region (Atlantic Forest) is occupied by the Cerrado, with intermediate resilience. 

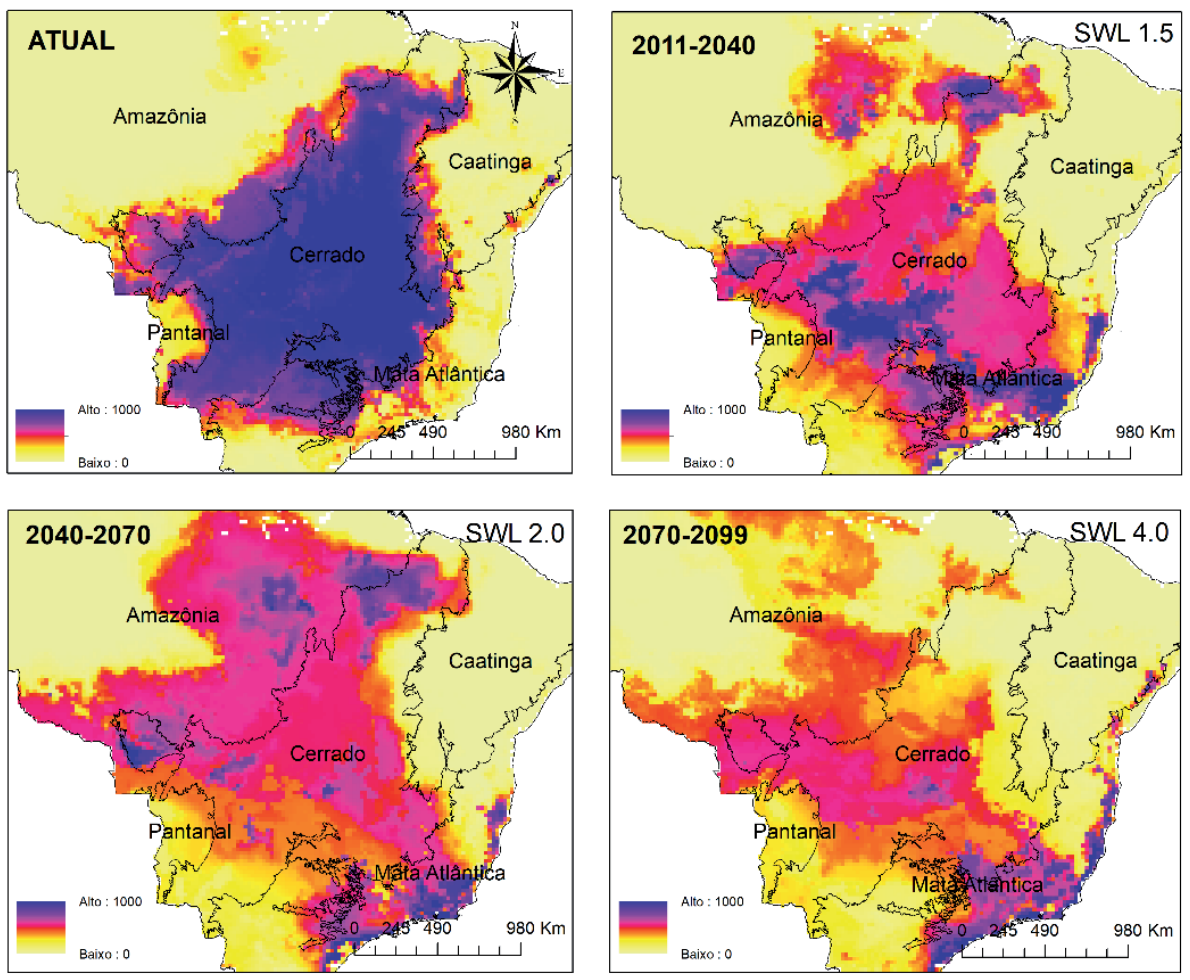

Figure 6 | Projection of Resilience alterations for the Cerrado (low: 0 to high:1000) at $1.5^{\circ} \mathrm{C}, 2^{\circ} \mathrm{C}$ and $4^{\circ} \mathrm{C}$

\section{Source: Authors.}

Under that perspective, the Cerrado presents less sensitivity to climate stress and good adaptive capacity when compared to forest biomes such as the Amazon and Atlantic Forest. The Cerrado also presents relative resilience and adaptability to fire episodes, which are the biome's ecology natural agents, and high-risk drivers for the Amazon biome. Likewise, results of the resilience assessment for the Cerrado biome have also been described by Zanin, Machado e Albernaz, 2016, and are compatible with the biome's results.

\section{ATLANTIC FOREST}

For the Atlantic Forest, the division pattern is very solid, with a relatively narrow high resilience range, with high temperature range $\left(12^{\circ} \mathrm{C}\right.$ to $\left.26^{\circ} \mathrm{C}\right)$, but with a more restrict range in terms of extreme rainfall $(\sim 1,200$ and 2,000 mm/year), which suggests a critical threshold $(\sim 1,200$ and 2,000 mm/year) for the Atlantic Forest to transition to another biome, like the Cerrado, as per Figure 7. For a warming level of $1.5^{\circ} \mathrm{C}$, a decline in biome occupation occurs, with significant resilience loss, that is, low resilience in the largest part occupied by the biome, and intermediate and high resilience concentrated in the cost. For a warming level relative to $\sim 2^{\circ} \mathrm{C}$, high resilience only occurs in small patches along the coastal region, much like the $4^{\circ} \mathrm{C}$ scenario, where most of the biome presents low resilience. 

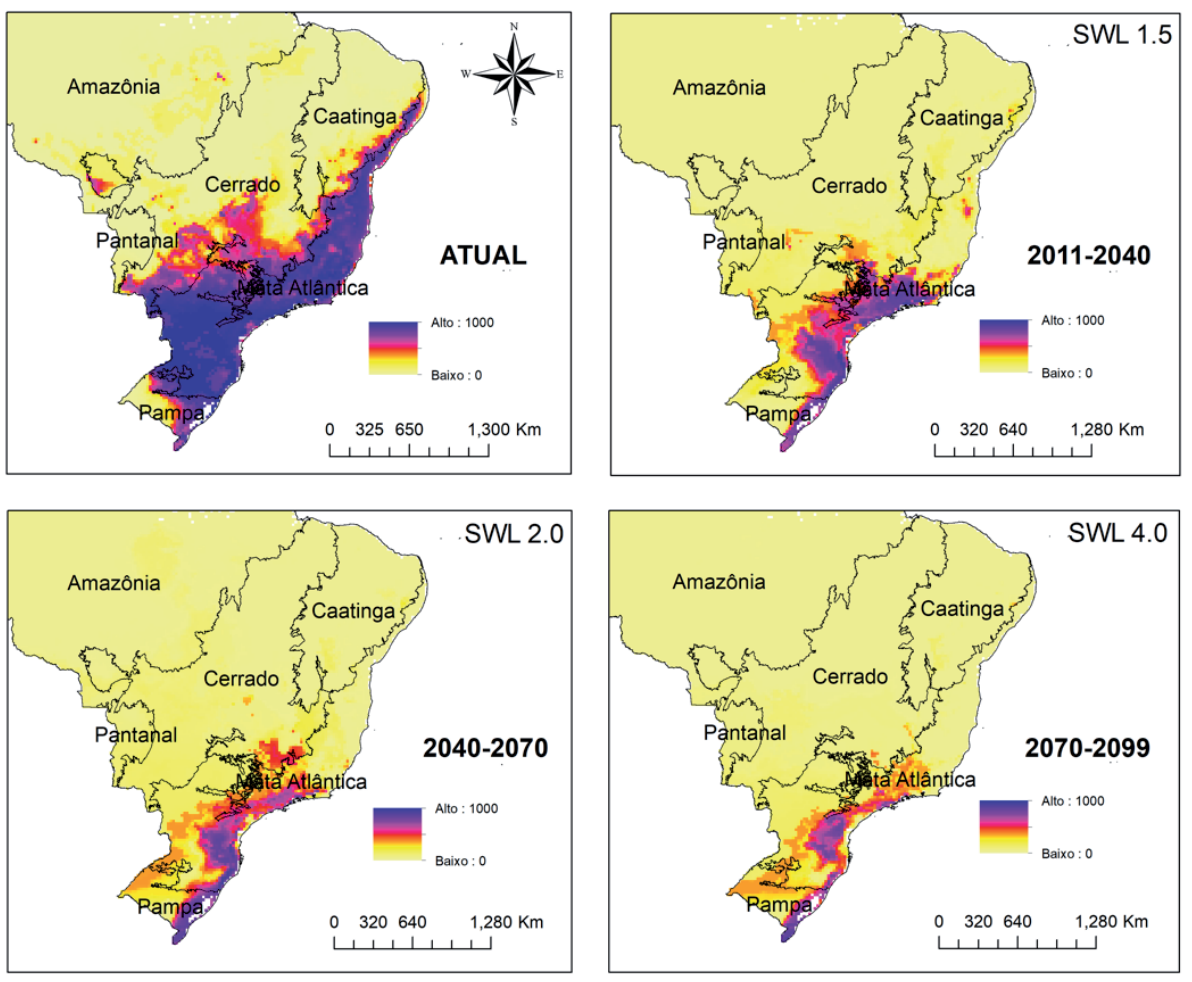

Figure 7 | Projection of Resilience alterations for the Atlantic Forest (low: 0 to high:1000) at $1.5^{\circ} \mathrm{C}, 2^{\circ} \mathrm{C}$ and $4^{\circ} \mathrm{C}$ Source: Authors.

\section{PAMPA}

For the Pampa, the temperature variation thresholds are the lowest $\left(18{ }^{\circ} \mathrm{C}-22{ }^{\circ} \mathrm{C}\right)$ with a relatively narrow rainfall range $(1,100$ to 2,000$)$ for high resilience, as shown in Figure 7 . The Pampa biome loses its high resilience at every warming level, and by the end of the century it is restricted to only a small fraction in the far south of the country. The biome also expands to other areas before occupied by the Cerrado at every warming level, but with low resilience. As indicated by modeling results, there is an upward trend in vulnerability to climate change in this biome, due to temperature increase projections and extreme rainfall events, which will affect its resilience and adaptive capacity. 

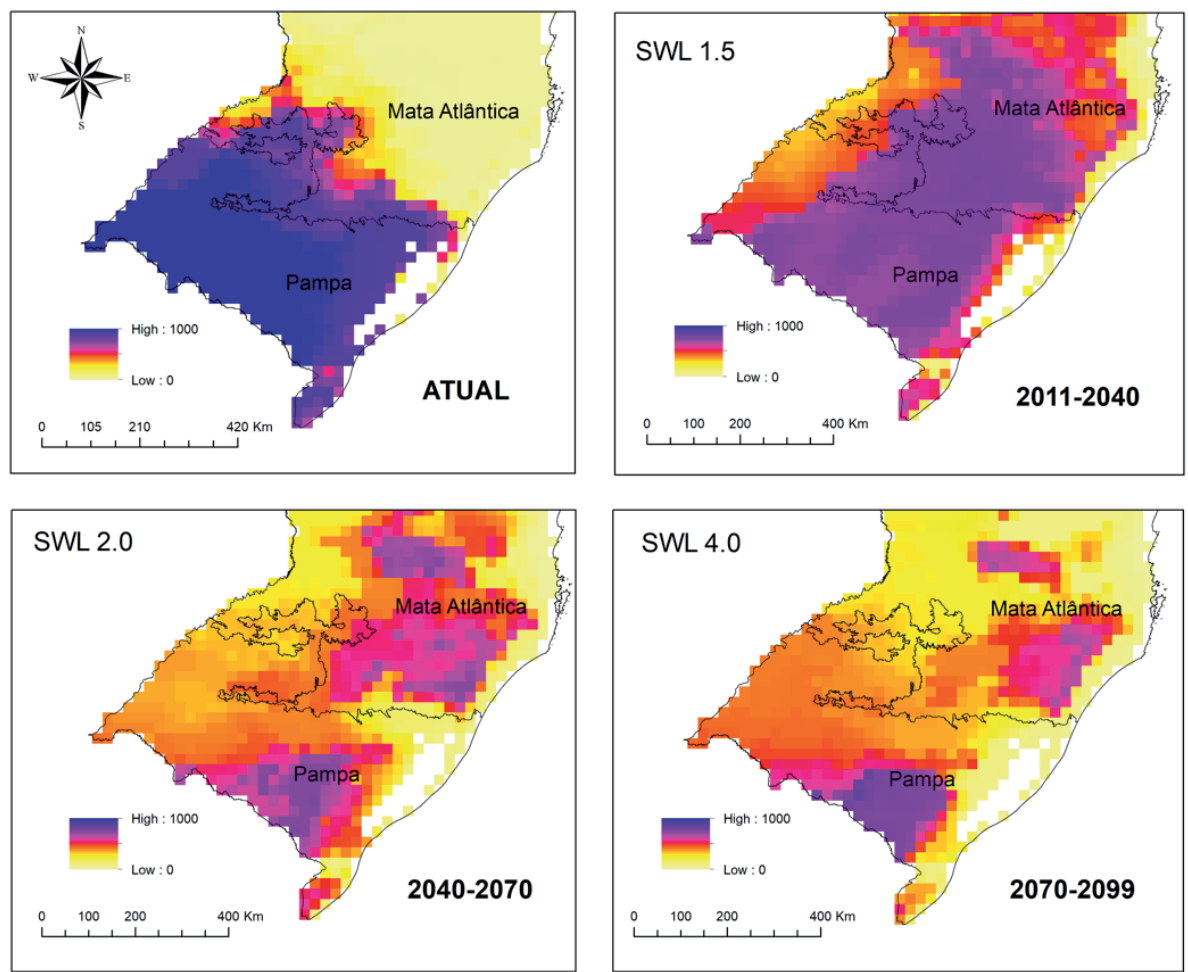

Figure 8 | Projection of Resilience alterations for the Pampa (low: 0 to high:1000) at $1.5^{\circ} \mathrm{C}, 2^{\circ} \mathrm{C}$ and $4^{\circ} \mathrm{C}$

\section{Source: Authors.}

\section{SOCIO-ENVIRONMENTAL RISKS PER BIOME}

For all biomes, resilience modeling shows that biodiversity loss is expected, and will compromises the functioning of ecosystems and the provision of ecosystem services to society.

Since the ecosystem resilience modeling presented herein does not include non-climate forcing specifically related to land-use changes, they were pointed out in this section in a quanti-qualitative way, which, when overlapped to resilience modeling per biome, points at the main socio-environmental vulnerabilities and risks in the future.

Current exposure and exposure associated to the main land-use change drivers, vulnerabilities, potential future impacts and projected impacts for the biome by 2100 are presented herein as inferred socioenvironmental risks, associated to climate change with resilience loss as evidenced by the ecological niche modeling. Although there are multiple land-use change drivers, as well as vulnerabilities to climate change that are not described in this analysis, some of the most evident examples for each biome, available in the literature in the past decade, were selected.

The Amazon will lose its capacity as a carbon sink, a climate regulation ecosystem service of global relevance (LAPOLA et al 2018; O'NEILL et al. 2017). Current the deforestation level that have intensified, together with an increase in forest fires and precarious and rapid urbanization are exposing the population and ecosystems to greater impacts from climate extremes. The effects of climate change and land use lead to increased tree mortality, reduced forest biomass and increased incidence of fire episodes, loss of biodiversity and ecosystem services (ANJOS e TOLEDO, 2018; OMETTO et al., 2018)

Given the importance of biodiversity to livelihoods of indigenous and traditional people they are highly vulnerable to climate extremes in the region (BRONDíZIO et al., 2016; PINHO, 2016; PINHO, 
MARENGO e SMITH, 2015). Both the rural and urban poor populations have low capacity to cope with extreme climate impacts associated with factors of poverty, marginalization and low State presence (MARU et al., 2014). If urgent adaptation measures are not advanced, the loss of ecosystem services and biodiversity, which are essential for livelihoods, economy and population wellbeing, will be even greater (BRONDÍZIO et al., 2016; LAPOLA et al., 2018).

Furthermore, it is expected that social costs associated with climate change projected in a scenario without adaptation by 2030 are mostly underestimated. For instance, there are no assessments on costs of migration associated with loss of livelihoods associated with climate impacts, but there is evidence that new migration flows will occur in the Amazon by 2030 due to climate extremes. This will bring high social costs, since migrants end up occupying marginal spaces and precarious housing and jobs in bigger cities like Manaus and Boa Vista (LAPOLA et al., 2018). It is also expected that water supply will be compromised in the main rivers of the region at a $2^{\circ} \mathrm{C}$ warming, thus affecting food and water security in the Region (BETTS et al., 2018).

As pointed out for the Caatinga biome, it would present an expansion of high resilience areas, mainly over the part of the Atlantic Forest in the Northeast and the Cerrado, showing that it presents greater resilience to global temperature increase. However, the increased desertification incidence will cause a profound impact on food production, especially among family farmers, compromising local and regional food market supply.

This is so as $35 \%$ of all food production area by family farming is located in the Caatinga biome (EMBRAPA, 2014), and that family farmers are responsible for some $80 \%$ of the domestic diversitifcation of food production (Saraiva et al., 2018). Climate change impacts caused by desertification in the region have already been affecting food and water security among ruiral population (LINDOSO et al., 2014; MESQUITA, BURSZTYN e WITTMAN, 2014), and increasing poverty, potential conflicts and migration, that tend to intensify with the increase in the desertification process associated with climate change.

In the Cerrado and Atlantic Forest biomes, which also present a high level of endemism and are global biodiversity hotspots (Myers et al., 2000), vulnerabilities related to the high reduction of the original vegetation cover, enhanced by a strong degradation pressure that continues on remnants, mainly associated to agricultural practices of commodities, livestock and urbanization, together with the relatively low number of protected areas (CARLOS A. JOLY, MAÍRA C. G. PADGURSCHI e et al., 2018). Moreover, in the case of the Cerrado biome, it is estimated that a reduction in water availability will compromise commodities production, mostly soybeans (Strassburg et al., 2017), and potentially family farming, along with an increase in the incidence of dengue fever (Perez et al herein) and heat waves (LAPOLA et al., 2019).

It is expected that the Atlantic Forest experiences loss of ecosystem services of pollination with a global temperature increase, will compromising food production (GIANNINI et al., 2017). The only non-biome areas that will potentially remain resilient to climate change are currently anthropogenic environments, showing the need to invest in reforestation of native vegetation in areas identified as critical for high resilience. Although a drastic reduction in deforestation in the Atlantic Forest (SOS Mata Atlântica, 2018) has occurred over the recent years, the investments and actions to recover native vegetation and increase fragment connectivity are still incipient in order to ensure ecological processes, biodiversity and the provision of ecosystem services.

In the Pampa, vulnerability to climate extremes is relatively high, and just as in the Atlantic Forest, it is so due to historical deforestation processes, with only $26 \%$ left of native vegetation (BUSTAMANTE, METZGER e et al., 2018). The low native vegetation cover, high habitat fragmentation, and less than $3 \%$ of protected areas in the Pampa represent a low adaptive capacity in the face of climate change (Bustamante, Metzger e et al., 2018; Jenkins et al., 2015). In addition, agricultural activities have favored the invasion of herbaceous species in the Pampa, and change the cycle of fire and incidence 
of the Aedes aegypti (Culicidae) mosquito, contributing to the spread of cases of dengue fever, yellow fever, zika and chikungunya fever, which compete with native species, cause damage to agriculture and is a human-disease vector (BUSTAMANTE, METZGER e et al., 2018).

Some gaps have been identified in the scientific field, mainly the strong disparity in the availability of studies that explore evidence of climate-related impacts and future scenarios among biomes. Therefore, it is necessary to advance studies on the observed climate change impacts and projections on ecosystem services and human wellbeing, according to the socio-environmental approach, so that all the Brazilian biomes, cities and coastal zones are represented in science and priority actions on mitigation and adaptation to climate change.

Additionally, studies mapping material and non-material losses associated to climate change, such as changes in human wellbeing, loss of cultural values due to land conflicts and migratory flows that might be enhanced with climate change are crucial to advance adaptive strategies for the reduction of systemic risks for socio-environmental security in the country. Likewise, studies that give priority to explaining ecological and social tipping points for the different biomes in the global warming processes have contributed with knowledge on socio-environmental resilience in tropical areas, which is still a somewhat new field of study.

\section{CONCLUSION}

Climate change, caused by the increase in the global average temperature expected for the next decades within the end of the century, related to an increase in greenhouse gases (GHG), reduces ecosystem resilience in all biomes, incurring loss of biodiversity and ecosystem services and increased exposure and socio-environmental vulnerabilities. At first instance, the Caatinga is the most resilient biome in the face of the global average temperature increase, and the Amazon, Atlantic Forest and the Cerrado are more likely to lose resilience.

Results of resilience loss shown herein, for example, in the Amazon biome, contribute to "moderate" and "extreme" estimates, conditioned to the severity of the forest's dieback process, which means that at least $30 \%$ and $50 \%$ of the Amazon forest area would be lost due to climate change, respectively (KRIEGLER et al., 2009), and that deforestation caused by direct human activities would be kept in less than $20 \%$ of the forest area (LOVEJOY e NOBRE, 2018)Brazilian scientist Eneas Salati shattered the long held dogma that vegetation is simply the consequence of climate and has no influence on climate whatsoever ( 1 .

For the Caatinga, the aridization process is enhanced (ACOSTA SALVATIERRA et al., 2017) and advances towards other possible areas occupied by the Atlantic Forest, mainly in the coastal region (ZANIN, MACHADO e ALBERNAZ, 2016). In the Atlantic Forest and the Cerrado biomes, large-scale production of agricultural commodities, especially for the foreign market, will experience significant losses (Lapola et al., 2014). These losses, in turn, represent concrete threats to a number of sectors in the economy, namely agriculture and energy generation, as well as to the survival of traditional people and communities.

Therefore, efforts to limit global warming, as well as actions and policies towards adaptation and vulnerability reduction at the local and regional level are paramount to reduce risks to socio-environmental security. There is high confidence that by limiting climate change to $1.5^{\circ} \mathrm{C}$ instead of $2^{\circ} \mathrm{C}$ by 2040 will reduce risks to unique and threatened ecosystems, thus protecting ecosystem services for populations' livelihoods and providing better opportunities for adaptation to climate change and promotion of sustainable development (B.C. O' NEILL et al. 2017; BATHIANY et al. 2018; ROY et al. 2018), particularly in biodiverse ecosystems such as the Amazon, Cerrado, Caatinga and Atlantic Forest. Moreover, investment in reforestation and the establishment of protected areas, sustainable development areas, and delimitation of indigenous territories based on the legislation in force, as well as command and control mechanisms, contribute to reduce biome exposure and vulnerabilities to global warming. 
The global proposals to implement nature-based solutions, such as ecosystem-based adaptation (EbA) can directly contribute to the mitigation and adaptation to climate change agenda (Seddon et al., 2020) and urgently need to move forward in Brazil (Kasecker et al., 2018). Especially in tropical countries, the ecosystem resilience may and shall be strengthened at the present moment so that they may play their vital role in tackling the climate crisis (Malhi et al., 2020).

\section{REFERENCES}

ALLOUCHE, O.; TSOAR, A.; KADMON, R. Assessing the accuracy of species distribution models: prevalence, kappa and the true skill statistic (TSS). Journal of Applied Ecology, v. 43, n. 6, p. 1223-1232, set. 2006.

AMBRIZZI, T. et al. Cenários regionalizados de clima no Brasil para o século XXI: projeções de clima usando três modelos regionais. Ministério do Meio Ambiente. Secretaria de Biodiversidade e Florestas. Diretoria de Conservação da Biodiversidade - Mudanças climáticas globais e efeitos sobre a biodiversidade. Subprojeto: caracterização do clima atual e definição das alterações climáticas, v. 3, p. 112, 2007.

ANADÓN, J. D.; SALA, O. E.; MAESTRE, F. T. Climate change will increase savannas at the expense of forests and treeless vegetation in tropical and subtropical Americas. Journal of Ecology, 2014.

ANJOS, L. J. S.; TOLEDO, P. M. DE. Measuring resilience and assessing vulnerability of terrestrial ecosystems to climate change in South America. PLOS ONE, v. 13, n. 3, p. e0194654, 19 mar. 2018.

BETTS, R. A. et al. Changes in climate extremes, fresh water availability and vulnerability to food insecurity projected at $1.5^{\circ} \mathrm{C}$ and $2^{\circ} \mathrm{C}$ global warming with a higher-resolution global climate model. Phil. Trans. R. Soc. Lond. A, v. 376, 2018.

BRONDÍZIO, E. S. et al. Social and health dimensions of climate change in the Amazon Annals of Human Biology, 2016. Disponível em: <http://www.tandfonline.com/doi/full/10.1080/03014460.2016.1193222>

BURKE, M.; HSIANG, S. M.; MIGUEL, E. Global non-linear effect of temperature on economic production. Nature, V. 527, n. $7577,2015$.

CARLETON, T. A.; HSIANG, S. M. Social and economic impacts of climate. Science, 2016.

CHAMBERS, J. C.; ALLEN, C. R.; CUSHMAN, S. A. Operationalizing Ecological Resilience Concepts for Managing Species and Ecosystems at Risk. Frontiers in Ecology and Evolution, 2019.

CHOU, S. C. et al. Evaluation of the Eta Simulations Nested in Three Global Climate Models. American Journal of Climate Change, 2014.

COMER, P. J. et al. Habitat climate change vulnerability index applied to major vegetation types of thewestern interior United States. Land, 2019.

DINIZ FILHO, J. A. F. et al. Partitioning and mapping uncertainties in ensembles of forecasts of species turnover under climate change. Ecography, v. 32, n. 6, p. 897-906, dez. 2009.

DONOGHUE, M. J.; EDWARDS, E. J. Biome Shifts and Niche Evolution in Plants. Annual Review of Ecology, Evolution, and Systematics, v. 45, n. 1, p. 547-572, 2014.

EMBRAPA. Agricultura familiar no Brasil.

FOLKE, C. et al. Regime shifts, resilience, and biodiversity in ecosystem management. Annual Review of Ecology, Evolution, and Systematics, 2004.

GIANNINI, T. C. et al. Projected climate change threatens pollinators and crop production in Brazil. PLOS ONE, V. 12, n. 8, p. e0182274, 9 ago. 2017.

GUNDERSON, L. H. Ecological Resilience: in theory and application. Annual Review of Ecology and Systematics, 
v. 31 , n. 1 , p. $425-439$, nov. 2000.

HIROTA, M. et al. Global resilience of tropical forest and savanna to critical transitions. Science, 2011.

JOLY, C. A. et al. $1^{\circ}$ Diagnóstico Brasileiro de Biodiversidade e Serviços Ecossistêmicos. Plataforma Brasileira de Biodiversidade e Serviços Ecossistêmicos, 2018.

KASECKER, T. P. et al. Ecosystem-based adaptation to climate change: defining hotspot municipalities for policy design and implementation in Brazil. Mitigation and Adaptation Strategies for Global Change, 2018.

KRIEGLER, E. et al. Imprecise probability assessment of tipping points in the climate system. Proceedings of the National Academy of Sciences of the United States of America, 2009.

LAPOLA, D. M. et al. Pervasive transition of the Brazilian land-use system. Nature Climate Change, v. 4, n. 1, p. 27-35, 1 jan. 2014.

Limiting the high impacts of Amazon forest dieback with no-regrets science and policy action. Proceedings of the National Academy of Sciences, v. 115, n. 46, p. 11671-11679, 13 nov. 2018.

Heat stress vulnerability and risk at the (super) local scale in six Brazilian capitals. Climatic Change, 2019.

LEHMANN, C. E. R. et al. Savanna Vegetation-Fire-Climate Relationships Differ Among Continents. Science, v. 343, n. January, p. 548-553, 2014.

LENTON, T. M. Environmental Tipping Points. Annual Review of Environment and Resources, v. 38, n. 1, p. 1-29, 2013.

LENTON, T. M. et al. Tipping elements in the Earth's climate system. Proceedings of the National Academy of Sciences, v. 105, n. 6, p. 1786-1793, 2008.

LINDOSO, D. P. et al. Integrated assessment of smallholder farming's vulnerability to drought in the Brazilian Semiarid: a case study in Ceará. Climatic Change, v. 127, n. 1, p. 93-105, 8 nov. 2014.

LOVEJOY, T. E.; NOBRE, C. Amazon Tipping Point. Science Advances, 2018.

MALHI, Y. et al. Climate change and ecosystems: threats, opportunities and solutions. Philosophical Transactions of the Royal Society B: Biological Sciences, v. 375, n. 1794, p. 20190104, 16 mar. 2020

MARENGO, J. A.; SCARANO, F. R. Impacto, vulnerabilidade e adaptação das cidades costeiras brasileiras às mudanças climáticas. Relatório Especial do Painel Brasileiro de Mudanças Climáticas (PBMC), p. 184, 2016.

MARU, Y. T. et al. A linked vulnerability and resilience framework for adaptation pathways in remote disadvantaged communities. Global Environmental Change, v. 28, p. 337-350, 2014.

MESQUITA, P.; BURSZTYN, M.; WITTMAN, H. Climate variability in semi-arid Brazil: food insecurity, agricultural production and adjustment to perceived changes. UNDP: International Policy Centre for Inclusive Growth. Disponível em: <https://pcc.uw.edu/wp-content/uploads/sites/15/2014/10/Sample-One-Pager-3.pdf.>. Acesso em: jun. 2017.

MYERS, N. et al. Biodiversity hotspots for conservation priorities. Nature, 2000.

NIKINMAA, L. et al. Reviewing the Use of Resilience Concepts in Forest Sciences. Current Forestry Reports, 2020.

OLIVERAS, I.; MALHI, Y. Many shades of green: the dynamic tropical forest-savanna transitions. Philosophical Transactions B. Biological Sciences, 2016.

OLSON, D. M. et al. Terrestrial Ecoregions of the World: a new map of life on earth. BioScience, v. 51, n. 11, p. 933, 2001.

OMETTO, J. P. et al. Interações entre Natureza e Sociedade: trajetórias do presente ao futuro. In: $1^{\circ}$ Diagnóstico Brasileiro de Biodiversidade e Serviços Ecossistêmicos. [s.l: s.n.]. p. 46. 
OPPENHEIMER, M. et al. Emergent Risks and Key Vulnerabilities. Climate Change 2014: impacts, adaptation, and vulnerability. Part A: Global and Sectoral Aspects. Contribution of Working Group II to the Fifth Assessment Report of the Intergovernmental Panel on Climate Change, p. 1039-1099, 2014.

PINHO, P. F. Watching Brazil but missing the story: an amazonian inferno. Latin American Studies Association. Special Issue on Environmental Justice and Climate Change in Latin America Lasaforum, Fall 2016, v. XLVIII, n. 4, p. 21-25, 2016.

PINHO, P. F.; MARENGO, J. A.; SMITH, M. S. Complex socio-ecological dynamics driven by extreme events in the Amazon. Regional Environmental Change, v. 15, n. 4, 2015.

RANGEL, T. F.; LOYOLA, R. D. Labeling ecological niche models. Natureza y Conservação, 2012.

REYER, C. P. O. et al. Forest resilience and tipping points at different spatio-temporal scales: approaches and challenges. Journal of Ecology, 2015.

SALVATIERRA, L. H. A. et al. Protected areas buffer the Brazilian semi-arid biome from climate change. Biotropica, 2017.

SARAIVA, A. et al. Contribuições da Natureza para Qualidade de Vida. In: SEIXAS, C. S. (Ed.). Plataforma Brasileira de Biodiversidade e Serviços Ecossistêmicos. [s.I: s.n.].

SCHEFFER, M. et al. Catastrophic shifts in ecosystems. Nature, v. 413, 2001.

Early-warning signals for critical transitions. Nature, v. 461, p. 53, set. 2009.

Anticipating Critical Transitions. Science, v. 338, n. 6.105, p. 344, p. 348, out. 2012.

SEDDON, N. et al. Understanding the value and limits of nature-based solutions to climate change and other global challenges. Philosophical Transactions of the Royal Society B. Biological Sciences, v. 375, n. 1794, p. 20190120, 16 mar. 2020.

SOS MATA ATLÂNTICA. Relatório Anual Sosma. São Paulo: [s.n.].

STRASSBURG, B. B. N. et al. Moment of truth for the Cerrado hotspot. Nature Ecology and Evolution, 2017.

THUILLER, W. et al. Biomod - A platform for ensemble forecasting of species distributions. Ecography, v. 32, n. 3, p. 369-373, jun. 2009.

ZANIN, M.; MACHADO, N.; ALBERNAZ, A. L. M. Mudanças climáticas e a cobertura vegetal nativa: impactos em um país megadiverso e seus biomas. In: Ministério da Ciência, Tecnologia e Inovação. (Ed.). Modelagem Climática e Vulnerabilidades Setoriais à Mudança do Clima no Brasil. [s.I: s.n.]. p. 93-125. 